\title{
THE EFFECT OF HYPOXIA AND RECUPERATION ON CARBOHYDRATE METABOLISM IN PACU (PIARACTUS MESOPOTAMICUS)
}

\author{
PANEPUCCI, R. A., PANEPUCCI, L., FERNANDES, M. N., SANCHES, J. R. \\ AND RANTIN, F. T. \\ Departamento de Ciências Fisiológicas, Universidade Federal de São Carlos, C.P. 676, CEP 13560-000, \\ São Carlos, Brazil \\ Correspondence to: Rodrigo A. Panepucci, Rua José Duarte de Souza, 203, Jd. Santa Paula, CEP 13564-030, \\ São Carlos, SP, Brazil, e-mail: frantin@ power.ufscar.br \\ Received May 22, 2000 - Accepted November 28, 2000 - Distributed November 30, 2001
}

(With 6 figures)

\begin{abstract}
A study of the hematological parameters, glycogen, glucose, and lactate, and the activity of malate and lactate dehydrogenases was carried out in blood and tissues of fishes submitted to two, four, and six hours of hypoxia and recuperation. Only after $4 \mathrm{~h}$ of hypoxia was there a drop in liver glucose. After $6 \mathrm{~h}$, a drop in lactate and a rise in glucose in practically all tissues signaled a recuperation of the metabolism, probably due to ASR (aerial surface respiration). Lactate formed during hypoxia was canalized to heart and brain for oxidation and used for neoglucogenesis. There were no changes in hematological parameters nore in the activity of malate and lactate dehydrogenases during normoxia and hypoxia, which suggest that these adaptive mechanisms may not be involved during hypoxia. Glycogen concentrations did not show variation during hypoxia either.
\end{abstract}

Key words: hypoxia, carbohydrate metabolism, dehydrogenases, fishes.

\section{RESUMO}

\section{O efeito da hipóxia e da recuperação sobre o metabolismo dos carboidratos no pacu} (Piaractus mesopotamicus)

Foram estudados os parâmetros hematológicos, glicogênio, glicose e lactato, e a atividade da malato e do lactato desidrogenases em sangue e tecidos de peixes, em normóxia, com diferentes tempos de hipóxia (até seis horas) e recuperação. Apenas após quatro horas de hipóxia o fígado utiliza glicose. Em seis horas de hipóxia, a queda de lactato e o aumento de glicose em praticamente todos os tecidos indicam uma recuperação por meio da RAS (respiração aérea superficial), presumivelmente realizada. O lactato produzido em hipóxia é reaproveitado como combustível oxidativo no coração e no cérebro e como substrato para a neoglicogênese. Não houve variações entre normóxia e hipóxia nos parâmetros hematológicos e na atividade das enzimas $\mathrm{LDH}$ e MDH, o que sugere que, provavelmente, esses mecanismos adaptativos não estão envolvidos na resposta ao ambiente hipóxico. Não ocorre variação nas concentrações de glicogênio entre normóxia e hipóxia.

Palavras-chave: hipóxia, metabolismo de carboidratos, desidrogenases, peixes.

\section{INTRODUCTION}

Recent studies have been directed towards a better understanding of ecological, behavioral, morphological, and physiological adaptations of tropical fishes (Saint-Paul \& Bernardino, 1988; Saint-Paul \& Soares, 1988; Rantin \& Kalinin, 1996; Rantin et al., 1998). Studies on biochemical adaptations are starting to provide interesting insights into the changes that occur when an organism 
is confronted with hypoxic waters (Almeida-Val \& Hochachka, 1993; Almeida-Val et al., 1995; Moraes et al., 1996). When this happens, the rate of oxygen delivery to the cells is less than that needed for oxidative metabolism to supply the energy they required. As a consequence, according to Dunn \& Hochachka (1986) and Dalla Via et al. (1994), a metabolic reorganization occurs that tends to follow one of two generalized patterns: either the rate of anaerobic ATP production increases (Pasteur effect) or the ATP rate declines (metabolic depression). This involves glycolytic activation with glycogen or glucose as the substrates and lactate as intermediate product.

A number of studies on many species have shown that fishes frequently respond to a change in environmental oxygen levels with changes within hematological parameters and alteration in physiological responses (Randall, 1993; Fernandes et al., 1995; Matsusaki et al., 1997). Enzymatic adaptations to hypoxia have already shown that there is a change in affinity of some enzymes involved in aerobic and anaerobic metabolism (Lushchak et al., 1997; Panepucci et al., 1998, 2000). Shaklee et al. (1977) found significant differences in enzymatic activity for liver LDH and white muscle aldolases in fishes acclimated to different oxygen concentrations.

Since the study of biochemical adaptations comprehending enzymatic activity and changes in intermediary metabolites together with hematological parameters seems appropriate to understand the changes involved during the events of hypoxia, the present work aimed at explaining how this three parameters are influenced by hypoxia in $P$. $m e$ sopotamicus.

\section{MATERIAL AND METHODS}

Specimens of $P$. mesopotamicus, were obtained from the Center of Research and Training in Aquaculture (Cepta/Ibama), Pirassununga, SP, Brazil. Pacu were acclimated to $25^{\circ} \mathrm{C}$ in $250 \mathrm{~L}$ holding tanks with continuous flow of dechlorinated and well-aerated water (oxygen water tension, $\mathrm{PW}_{\mathrm{O} 2}>130 \mathrm{~mm} \mathrm{Hg}$ ) for at least three weeks prior to experimentation. Fish, of approximately $300 \mathrm{~g}$, were fed with commercial food pellets ad libitum but fasted for two days prior to experimentation.

\section{Experimentation}

Six fishes were placed for each experiment in a special aquarium for 24 hours with proper aeration $\left(\mathrm{P}_{\mathrm{wO} 2}>130 \mathrm{~mm} \mathrm{Hg}\right)$. Oxygen tensions of water were measured continuously by $\mathrm{O}_{2}$ electrodes connected to a $\mathrm{O}_{2}$ analyzer. Water oxygen tensions inside the experimental chamber were gradually decreased until critical oxygen tensions of $\mathrm{PW}_{\mathrm{O} 2}$ of $15 \mathrm{~mm} \mathrm{Hg}$ were reached and kept at stable levels by bubbling $\mathrm{N}_{2}$. Eight different experiments were performed with six fishes each.

$1^{\text {st }}$ Control experiment, fishes in normal conditions. For glucose and lactate in blood and tissues.

$2^{\text {nd }}$ Two hours hypoxia. For glucose and lactate in blood and tissues.

$3^{\text {rd }}$ Four hours hypoxia. For glucose and lactate in blood and tissues.

$4^{\text {th }}$ Six hours hypoxia. For glucose and lactate in blood and tissues.

$5^{\text {th }}$ Two hours recuperation. Fishes submitted to six hours hypoxia and then two hours of normal conditions. For glucose and lactate in blood and tissues.

$6^{\text {th }}$ Four hours recuperation. Idem above and four hours normal conditions. For glucose and lactate in blood and tissues.

$7^{\text {th }}$ Six hours hypoxia for enzimatic and glycogen experiments on tissues.

$8^{\text {th }}$ Six hours normal conditions for enzimatic and glycogen experiments on tissues.

Fishes were anaesthetized (1:10,000, MS 222) and blood was withdrawn from the trunk via caudal vessel puncture; one part was placed in a tube for hematocrite, hemoglobin, and cell count and the other part, directly into 3 volumes of icecold $6 \%$ perchloric acid (PCA). Then fishes were killed with a blow to the head and tissues removed and frozen at $-80^{\circ} \mathrm{C}$ following Dunn \& Hochachka (1986).

\section{Enzyme preparation and assay of $L D H$ and $M D H$ activity}

White muscle, heart, liver, and brain tissues from fishes were weighed and homogenized at icetemperature with a 9-fold volume of Imidazol $5 \mathrm{mM}$, $\mathrm{KCN} 1 \mathrm{mM}, \mathrm{pH} 7.4$ (at $25^{\circ} \mathrm{C}$ ) buffer. The homogenate was centrifuged at $17,000 \mathrm{~g}$ at $5^{\circ} \mathrm{C}$ for $30 \mathrm{~min}$. The 
supernatant was used directly as an LDH and MDH source in the kinetic study. LDH and MDH activities were determined by following oxidation of NADH at $340 \mathrm{~nm}$ in a circulating thermobath at $25^{\circ} \mathrm{C}$. The reaction mixture was contained in a total volume of $1 \mathrm{ml}, 50 \mathrm{mM}$ Imidazol, $1 \mathrm{mM}$ KCN buffer $\mathrm{pH} 7.4$ at $25^{\circ} \mathrm{C}, 0.13 \mathrm{mM}$ of $\mathrm{NADH}$, and pyruvate $1 \mathrm{mM}$ for $\mathrm{LDH}$ and $0.3 \mathrm{mM}$. Oxalacetate for MDH activity of enzymes was expressed as U/gwt (unit per gram of wet tissue). One unit of enzyme activity is defined as the amount of enzyme utilizing $1 \mu$ mole of substrate per minute at $25^{\circ} \mathrm{C}$. Non-parametric Mann-Whitney test was used to estimate differences between experiments with fishes submitted to both hypoxic and normoxic conditions.

\section{Hematological parameters}

Hematocrite was made in duplicate and read using a percentage table after centrifugation. Hemoglobin was prepared after hemolising $10 \mu \mathrm{l}$ of blood in $2 \mathrm{ml}$ of ferricyanide-cianyde reagent and reading the optical density at $540 \mathrm{~nm}$. Blood cell count was determined in a Neubauer Count-Camera.

\section{Intermediate metabolites}

Blood and tissues were treated in 3 volumes of ice-cold $6 \%$ perchloric acid (PCA) homogenized in an ice cold bath and centrifuged at $3^{\circ} \mathrm{C}$. Extracts were used for glucose and lactate determinations. Sigma kits procedures n. 635 and 826-UV were used respectively.

\section{Glycogen extraction}

Glycogen extraction from tissues was performed by heating them with a strong alcali and precipitated by the addition of $95 \%$ ethanol. After hydrolised in acid, glucose was determined by the glicose oxidase method, Sigma procedure n. 510.

The non-parametric Mann-Whitney test was used to estimate differences by comparing data between control experiments realized in normoxia and experiments done during different times of hypoxia periods and experiments on recuperation for all experiments done.

\section{RESULTS AND DISCUSSION}

Activity of LDH, a glycolytic enzyme (Fig. 1), did not show significant differences between normoxia and six hours of hypoxia. In muscle, in accordance with its anaerobic metabolism, activities were almost
$50 \%$ higher than in heart. Brain and liver showing the lowest activity. It is interesting to note that the main enzyme indicator of anaerobic potential is LDH. MDH activity (Fig. 2) in different tissues did not show significant differences between normoxia and six hours of hypoxia. The highest activities were found in heart and liver, denoting aerobic metabolism in these organs in contrast with white muscle which showed a very low activity in accordance with its anaerobic metabolism. Panepucci et al. $(1998,1999)$ showed differences in enzyme affinity in Rhinelepis strigosa (Siluriformes, Loricariidae) after six hours of hypoxia but for P. mesopotamicus, this was probably too short a time to bring about a change in enzyme activity. Comparatively with other tissues, high activities of MDH in heart and liver denotes aerobic metabolism in these tissues.

Lactate experiments are shown in Fig. 3a and b. There is no significant lactate accumulation in white muscle after six hours of hypoxia (Fig. 3a). According to Jorgensen \& Mustafa (1980) significant significantly higher values of lactate in white muscle are only registered after 21 hours of hypoxia in flounder (Platichtys flesus). The other tissues and blood show a significant increases in lactate after up to four hours of hypoxia and then a drop after six hours of hypoxia. Increase in lactate after hypoxia denotes a increase in anaerobic metabolism as a source of energy. Lactate produced under hypoxia may be transferred to the blood and other tissues and even kept to be oxidized after return to normal conditions. The drop in lactate observed in six hours of hypoxia in all tissues except for muscle, may be due to aquatic surface respiration (ASR) that these fishes perform, specially after four hours of hypoxia (Rantin \& Kalinin, 1996; Rantin et al., 1998). Fig. 3b shows data on lactate concentrations of six hours of hypoxia and on recuperation after two and four hours of normal oxygenation. Muscle and brain do not show variations between hypoxia and normoxia. Heart and liver show significantly higher values in two and four hours of recuperation from six hours of hypoxia which is probably due to an import of lactate from blood to be oxidized, specially in heart, or to be used for neoglycogenesis, specially in liver. Farrel \& Steffensen (1987) estimated that blood lactate oxidation can fuel approximately $20 \%$ of cardiac aerobic metabolism at rest and $100 \%$ after exercise, which is consistent with findings of Milligan \& Girard (1993), showing that blood lactate is a preferred substrate for cardiac muscle metabolism. 


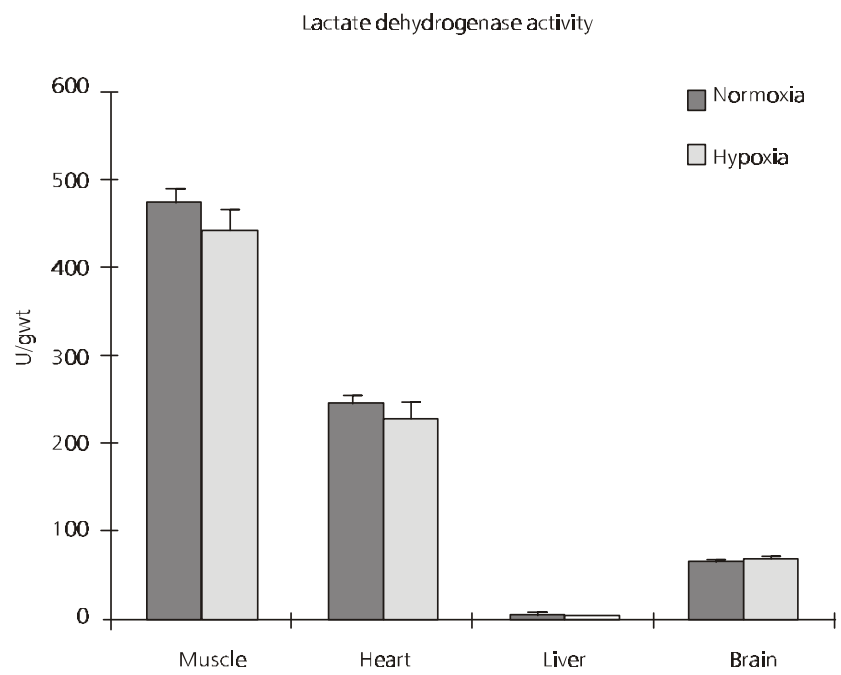

Fig. 1 - LDH, lactate dehydrogenase activity of different tissues from fishes submitted to normoxia and hypoxia for six hours. Error bars are within limits of symbols when not visible. U, $\mu$ mole substrate/min, gwt, gram of wet tissue. Values are means $\pm \mathrm{SD}, \mathrm{n}=6$.

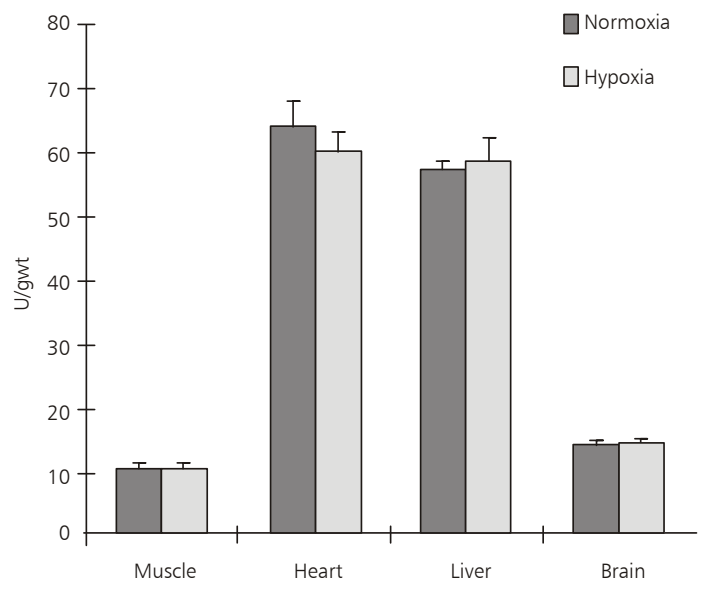

Fig. 2 - MDH, malate dehydrogenase activity of different tissues from fishes submitted to normoxia and hypoxia for six hours. Error bars are within limits of symbols when not visible. U, $\mu$ mole substrate/min, gwt, gram of wet tissue. Values are means $\pm \mathrm{SD}, \mathrm{n}=6$

This may indicate that, although a very small tissue, cardiac muscle has the potential to play a major role in the clearance of blood lactate.

Glucose changes during hypoxia and recuperation are showed in Fig. 4a and b. Blood did not change glucose concentrations during hypoxia, which may explain that increases and decreases of this metabolite occurred only within the tissues. Liver showed a sharp decrease after four hours of hypoxia and subsequent recuperation, probably due to ARS. The lack of glucose increase in liver supports the conclusion that glycogenolysis was not activated in the first four hours of hypoxia but that glucose was consumed to be reestablished to normal values after this period. Muscle, heart, and brain showed significant increases in glucose after six hours of hypoxia probably due to glycogenolysis activation. 


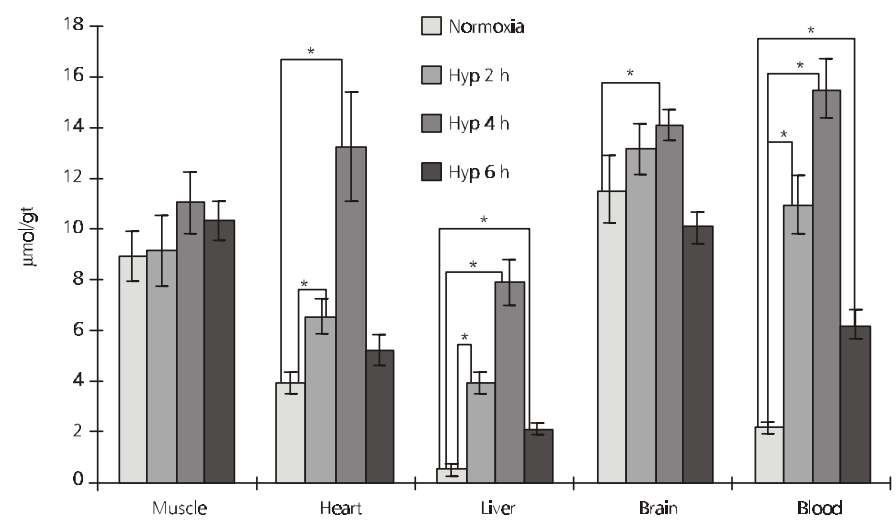
Lactate- Recuperation

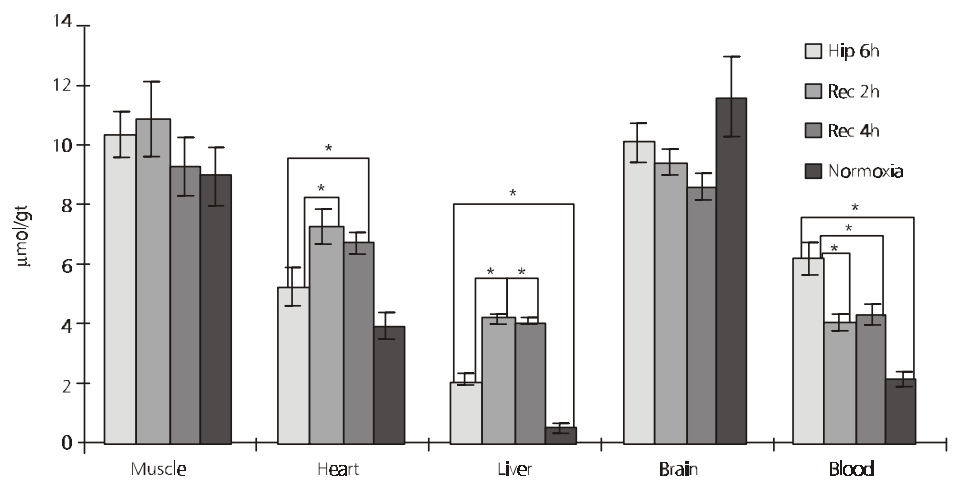

Fig. 3 - Lactate concentrations in different tissues of fishes submitted to normoxia and a) different periods of hypoxia; b) recuperation. Error bars are within limits of symbols when not visible. Values are means $\pm \mathrm{SD}, \mathrm{n}=6 . * \mathrm{p}<0.05$.

Dunn \& Hochachka (1986, 1987), both, reported an increase in trout glucose after hypoxia. According to Walton \& Cowey (1982), carbohydrate metabolism is not believed to be a major energy source in fish, but it is reasonable to assume that its importance increases during hypoxia because of activation of anaerobic glycolisis. Recuperation (Fig. 4b) showed an increase in glucose in liver and heart and a fluctuation in muscle and brain, suggesting that a four-hour period is a short time for recuperation and stabilization of normal values in this species.

Hematological parameters are shown in Figs. $5 \mathrm{a}, \mathrm{b}$, and $\mathrm{c}$. There were no significant changes in hematocrite, hemoglobin, and blood cell count between normoxia and six hour of hypoxia.

Glycogen deposits are used during hypoxia in many animals as a source of glucose for catabolism (Hochachka \& Somero, 1984; van Waarde et al., 1983). During this experiment, glycogen concentrations were unchanged after six hours of hypoxia in all tissues examined (Fig. 6). Glycogen levels were low according to Hochachka \& Somero (1984) and should be higher in liver than in other tissues. The disparity found in this study might have two explanations. First that very little glycogen was available and used for glucose increase in the tissues and second, that the methodology used for glycogen extraction was not accurate enough to detect the changes although extreme care was taken in all laboratory tasks.

Data on lactate permits corroboration of physiological experiments performed with P. mesopotamicus by Rantin \& Kalinin (1996) and Rantin et al. (1998) that showed that after four hours of acute hypoxia fishes perform ARS, which skims oxygenated surface water. 
a) Glucose- Hypoxia

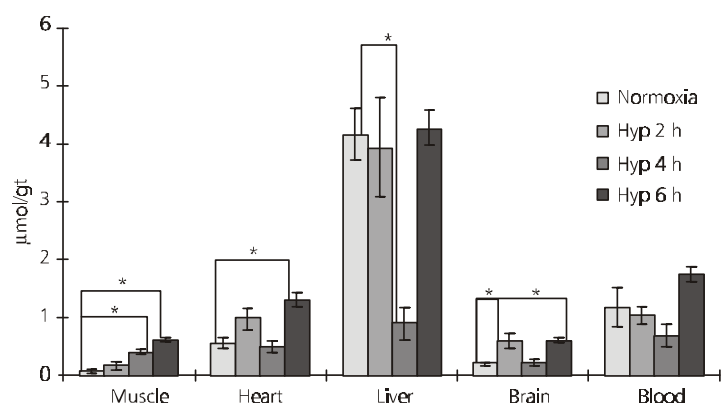

b)

Glucose-Recuperation

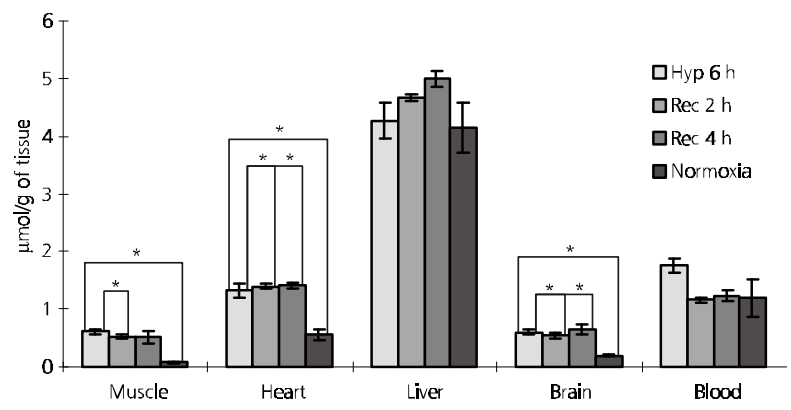

Fig. 4 - Glucose concentrations in different tissues of fishes submitted to normoxia and a) different periods of hypoxia, b) recuperation. Error bars are within limits of symbols when not visible. Values are means $6 \mathrm{SD}, \mathrm{n}=6 . * \mathrm{p}<0.05$.

a)

Hematocrite

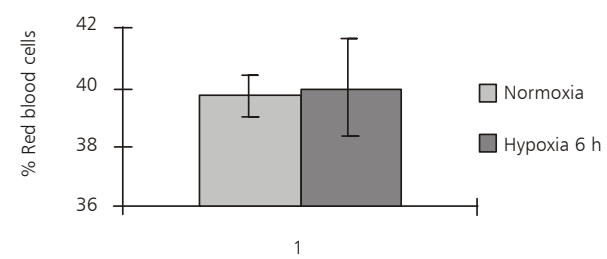

b)

Hemoglobin

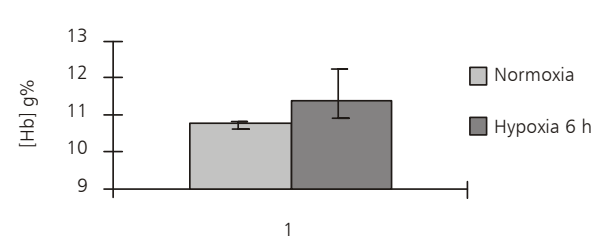

c)

Red blood cells

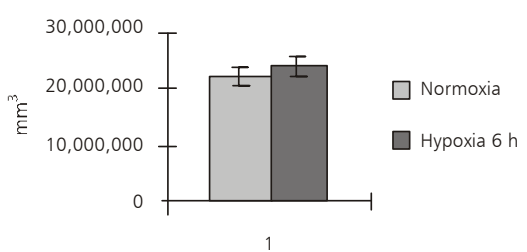

Fig. 5 - Hematological parameters of fishes submitted to normoxia and hypoxia for six hours: a) hematocrite; b) hemoglobin; and c) red blood cells. Error bars are within limits of symbols when not visible. Values are means \pm SD, $n=6$. 


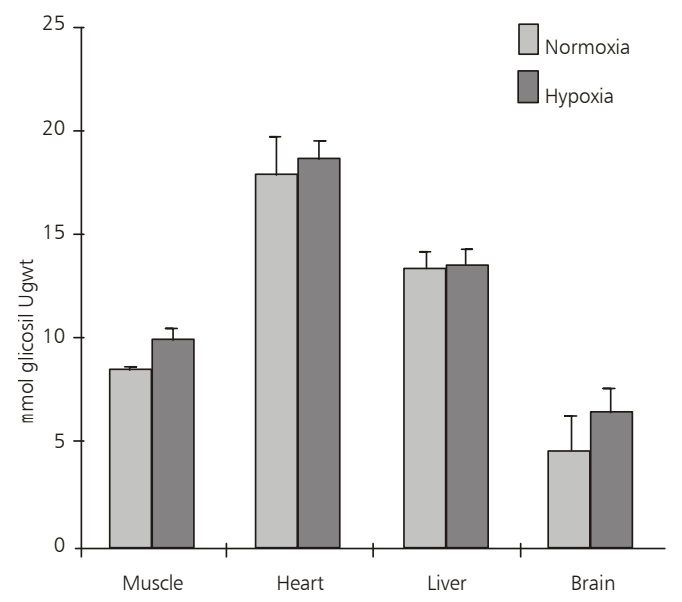

Fig. 6 - Glycogen concentrations in different tissues of fishes submitted to hypoxia for six hours. Error bars are within limits of symbols when not visible. Values are means $\pm S D, n=6$.

As this study shows, this helps to change its metabolism from anaerobic, accumulating lactate, to aerobic, reoxidating lactate to pyruvate to enable oxidative metabolism to continue through the Krebs cycle. Since this fish does not change hematological parameters and enzyme activities, like LDH and $\mathrm{MDH}$, which are key metabolic indicators of anaerobic and oxidative metabolism respectively, the mechanisms utilized by pacu to function in hypoxic waters is to rely on cardiorespiratory changes, regulating oxygen supplies through ASR and also anaerobic glycolisis as was shown in the present report. This set of arrangements greatly increases this species' adaptation to anaerobic environments.

\section{REFERENCES}

ALMEIDA-VAL, V. M. F. \& HOCHACHKA, P. W., 1993, Hypoxia tolerance in Amazon fishes: Status of an underexplored biological "goldmine". In: P. W. Hochachka, P. L. Lutz, T. Sick, M. Rosenthal \& G. Van den Thillart (eds.), Surviving hypoxia: Mechanisms of Control and Adaptation. CRC Press, Boca Raton, pp. 435-445.

ALMEIDA-VAL, V. M. F., FARIAS, I. P., SILVA, M. N. P., DUNCAN, W. P. \& VAL, A. L., 1995, Biochemical adjustments to hypoxia by Amazon cichlids. Braz. J. Med. Biol. Res., 28: 1257-1263.
DALLA VIA, J., VAN DEN THILLART, G., CATTANI, O. \& DE ZWANN, A., 1994, Influence of long term hypoxia exposure on the energy metabolism of Solea solea. II Intermediary metabolism in blood, liver and muscle. Mar. Ecol. Prog. Ser., 111: 17-27.

DUNN, J. F. \& HOCHACHKA, P. W., 1986, Metabolic responses of trout (Salmo gardnieri) to acute environmental hypoxia. J. Exp. Biol., 123: 229-242.

DUNN, J. F. \& HOCHACHKA, P. W., 1987, Turnover rates of glucose and lactate in rainbow trout during acute hypoxia. Can. J. Zool., 65: 1114-1148.

FARREL, A. P. \& STEFFENSEN, J. F., 1987, An analysis of the energetic cost of the branchial and cardiac pumps during sustained swimming in trout. Fish Physiol. Biochem., 4: 73-79.

FERNANDES, M. N., SANCHES, J. R. \& RANTIN, F. T., 1995, Effects of long and short-term changes in water temperature on the cardiac and respiratory responses to hypoxia of the air-breathing fish, Hypostomus regani. Proceedings of the International Congress of Comparative Physiology and Biochemistry. Physiol. Zool., 68(4): 67.

HOCHACHKA, P. W. \& SOMERO, G., 1984, Biochemical Adaptation. Princeton University Press, Princeton, NJ, $538 \mathrm{p}$.

JORGENSEN, J. B. \& MUSTAFA, T., 1980, The efect of hypoxia on carbohydrate metabolism in Flounder (Platichtys flesus) I. Utilization of glicogen and accumulation of glycolytic end products in various tissues. Comp. Biochem. Physiol. Vol. 67B, pp. 233-248. 
LUSHCHAK, V. I., BAHNJUKOVA, T. V. \& SPICHENKOV, A. V., 1997, Modification of pyruvate kinase and lactate dehydrogenase in foot muscle of the sea mussel Mytilus galloprovincialis under anaerobiosis and recovery. Braz. J. Med. Biol. Res., 30(3): 381-385.

MATSUSAKI, M., SANCHES, J. R., FERNANDES, M. N. \& PANEPUCCI, L., 1997, Parâmetros hematológicos de cascudo, Hypostomus regani, em normoxia e submetidos a hipóxia ambiental em diferentes temperaturas de aclimatação. XII Encontro Brasileiro de Ictiologia. USP, São Paulo, fevereiro de 1997.

MILLIGAN, C. L. \& GIRARD, S. S., 1993, Lactate metabolism in rainbow trout. J. Exp. Biol., 180: 175-193.

MORAES, G., OLIVEIRA, M. A. de \& RANTIN, F. T., 1996, The metabolic pattern changes of Hoplias malabaricus from normoxia to hypoxic conditions. Rev. Brasil. Biol., 56(2): 191-196.

PANEPUCCI, L., FERNANDES, M. N., SANCHES, J. R. \& RANTIN, F. T., 2000, Changes in lactate dehydrogenase and malate dehydrogenase activities during hypoxia and after temperature acclimation in the armored fish, $R$ hinelepis strigosa (Siluriformes, Loricariidae). Rev. Brasil. Biol., 60(2): 353-360.

PANEPUCCI, L., FERNANDES, M. N., SANCHES, J. R. \& RANTIN, F. T., 1998, Changes in lactate dehydrogenase and malate dehydrogenase during hypoxia and after temperature acclimation in the armored fish, Rhinelepis strigosa (Siluriformes, Loricariidae). Proceeding of the International Congress on the Biology of Fish. July, Maryland, Baltimore MD USA.

PANEPUCCI, R., PANEPUCCI, L., SANCHES, J. R., FERNANDES, M. N. \& RANTIN, F. T., 1999, Metabolismo de pacu Piaractus mesopotamicus (Serrasalmidae) em normóxia e em diferentes tempos de hipóxia e recuperação. XII Encontro Brasileiro de Ictiologia. UFSCar, São Carlos, 22 a 26 de fevereiro.

RANDALL, D. J., 1993, The regulation of breathing in aquatic vertebrates. In: J. E. P. W. Bicudo (ed.), The Vertebrate Gas Transport Cascade. Adaptations to Environment and Mode of Life, Boca Raton, FL, CRC Press, pp. 54-59.
RANTIN, F. T. \& KALININ, A. L., 1996, Cardiorespiratory function and aquatic surface respiration in serrasalmid fish Colossoma macropomum exposed to graded and acute hypoxia. In: A. L. Val, V. M. F. Almeida-Val \& D. J. Randall (eds.), Physiology and Biochemistry of the Fishes of the Amazon. Editora do INPA, Manaus, Brazil, pp. 169-180.

RANTIN, F. T., ROSARIO GUERRA, C. Del, KALININ, A. L. \& GLASS, M. L., 1998, The influence of aquatic surface respiration (ARS) on cardio-respiratory function of the serrasalmid fish Piaractus mesopotamicus. Comp. Biochem. Physiol. A, 119: 991-997.

SAINT-PAUL, U. \& BERNARDINO, G., 1988, Behavioral and ecomorphological responses of the neotropical pacu (Piaractus mesopotamicus - Teleostei, Serrasalmidae) to oxygen-deficient waters. Exp. Biol., 48: 19-26.

SAINT-PAUL, U. \& SOARES, G. M., 1988, Ecomorphological adaptations to oxygen deficiency in Amazon flood plains by serrasamid fish of the genus Mylossoma. J. Fish Biol., 32: 231-236.

SHAKLEE, J. B., CHRISTIANSEN, J. A., SIDELL, B. D., PROSSER, C. L. \& WHITT, G. S., 1977, Molecular aspects of temperature acclimation in fish: Contributions of changes in enzymes patterns to metrabolic reorganization in the green sun fish. J. Exp. Zool., 201: 1-20.

VAN WAARDE, A., VAN DEN THILLART, G. \& KESBEKE, F., 1983, Anaerobic energy metabolism of the European eel, Anguilla anguilla L. J. Comp. Physiol., 149: 469-475.

WALTON, M. J. \& COWEY, C. B., 1982, Aspects of intermediary metabolism in salmonid fish. Comp. Biochem. Physiol., 73B: 59-79. 